TORUŃSKIE STUDIA BIBLIOLOGICZNE

2012, nr 2 (9)

Justyna Jerzyk-Wojtecka

Biblioteka Uniwersytetu Łódzkiego

e-mail: justyna.wojtecka@lib.uni.lodz.pl

\title{
Program wdrażania szkoleń information liferacy w bibliotece akademickiej na przykładzie Biblioteki Uniwersytetu tódzkiego: omówienie pilotażowego badania ankietowego
}

STRESzCzEnIE: Artykuł we wstępie omawia zagadnienia teoretyczne związane z wdrażaniem programu szkoleń information literacy w bibliotece akademickiej i zagraniczne doświadczenia w tej dziedzinie. Dalsza część jest poświęcona badaniu ankietowemu przeprowadzonemu wśród studentów oraz doktorantów Uniwersytetu Łódzkiego, mającemu na celu sprawdzenie wiedzy z zakresu information literacy oraz gotowości do wzięcia udziału w kursie o takiej tematyce. W zakończeniu znalazły się wnioski z badania, stanowiące wstępne wytyczne dla tworzonego programu szkoleń.

SŁoWA KLUCzowe: badania ankietowe, informacja naukowa, kompetencje informacyjne, szkolenia w zakresie information literacy

\section{Teoria i praktyczne zastosowanie information literacy}

Information literacy (dalej: IL) i problematyka związana z kompetencjami informacyjnymi pojawiły się w bibliotekarstwie w wyniku gwałtownego rozwoju elektronicznych, dostępnych sieciowo narzędzi informacji naukowej. Powstanie wielu baz danych, e-czasopism, e-książek i całego 
asortymentu różnorodnie skonstruowanych wyszukiwarek spowodowało rewolucję $\mathrm{w}$ dotychczasowym dostępie do wiedzy i informacji. Użytkownik biblioteki naukowej może dzisiaj przeczytać potrzebny mu artykuł naukowy w każdym miejscu, siedząc w pociągu czy autobusie, bez kontaktowania się z biblioteką i bibliotekarzem. Może, ale żeby to zrobić, musi wiedzieć, gdzie i jak taki artykuł znaleźć oraz w jaki sposób otworzyć go na swoim komputerze, iPodzie czy innym przenośnym czytniku elektronicznym.

IL po polsku oznacza alfabetyzację informacyjną, ale to kojarzące się $\mathrm{z}$ analfabetyzmem określenie coraz częściej jest zastępowane przez termin kompetencje informacyjne. Od lat trwają próby precyzyjnego zdefiniowania tego pojęcia ${ }^{1}$. Najczęściej cytowana i używana jest definicja przyjęta przez American Library Association: „Osoba posiadająca kompetencje informacyjne musi być w stanie określić własne potrzeby informacyjne, zlokalizować potrzebną informację, ocenić ją i efektywnie wykorzystać. To osoby, które nauczyły się, jak się uczyć"2.

Jak podkreślają autorzy zagraniczni, którzy pierwsze doświadczenia we wdrażaniu cyklów szkoleń z IL mają już za sobą, na początku takiej działalności istotne są dwa czynniki: pierwszy - to nawiązanie ścisłej współpracy z pracownikami naukowymi wydziałów, drugi - dokładne rozpoznanie potrzeb studentów.

Problematyka współpracy polskich nauczycieli akademickich i bibliotekarzy w dziedzinie rozwijania kompetencji informacyjnych studentów jest bardzo obszerna i z pewnością warta dokładnej analizy, na którą niestety brakuje miejsca $w$ niniejszym artykule. Z całą pewnością takie współdziałanie powinno prowadzić do określenia, jakie kompetencje informacyjne studentów są niezbędne do ich dalszej edukacji oraz do włączenia wiedzy z zakresu IL do praktycznego rozwiązywania zadań badawczych ${ }^{4}$. Z drugiej strony trzeba być świadomym, że taka współpraca

${ }^{1} \mathrm{~J}$. Lau, Kompetencje informacyjne $w$ procesie uczenia się przez całe życie [on-line]. Warszawa: SBP, 2006, 86 s. [dostęp 30 listopada 2012]. Dostępny w World Wide Web: http://www.ifla.org/files/information-literacy/publications/ifla-guidelines-pl.pdf.

2 Tamże.

${ }^{3}$ R. E. Johnson, ILS and RTP: Support to researchers provided by Information and Learning Services as part of the research training programme at the University of Worcester, past, present and future, „Journal of Information Literacy” 2011, vol. 5, iss. 1, s. 36; S. Bury, Faculty attitudes, perceptions and experiences of information literacy: a study across multiple disciplinesat York University, Canada, „Journal of Information Literacy” 2011, vol. 5, iss. 1 , s. 46.

${ }^{4}$ J. Lau, dz. cyt. 
może wywołać różnego rodzaju problemy, wynikające często ze stereotypowego myślenia, jak np. zawężenie roli bibliotekarza do świadczenia usług informacyjnych, a nie prowadzenia zajęć uniwersyteckich5; czy też zbyt sztywne, „bibliotekarskie” (a nie dziedzinowe) podejście do nauczania IL, co może być mało przydatne i nużące dla studentów.

$\mathrm{Z}$ reguły szkolenia w zakresie IL są przeznaczone dla studentów piszących prace dyplomowe lub doktorantów. Ich wytyczne programowe przygotowują nauczyciele akademiccy. Choć są one niezbędne, trudno jednak przygotować i prowadzić szkolenia bez informacji o wstępnym poziomie wiedzy grupy, którą mamy szkolić. Opracowany program kursu, aby był faktycznie efektywny, należy przystosować do poziomu wiedzy uczestników, ich potrzeb i zainteresowań. Warto także pamiętać o wskazówkach jednego z teoretyków andragogiki, Malcolma S. Knowlesa, który stwierdza, że dorośli łatwiej angażują się w proces nauczania, jeśli wiedzą, do czego prezentowana wiedza będzie przydatna i że jest ona zgodna z ich potrzebami ${ }^{6}$.

Obecnie również w Polsce rozwijanie kompetencji informacyjnych użytkowników staje się w coraz większym stopniu składnikiem usług bibliotecznych, szczególnie w przypadku bibliotek naukowych. Przysposobienie biblioteczne, prowadzone coraz częściej on-line, bez bezpośredniego kontaktu z bibliotekarzem, można określić jako zaledwie wstęp do znacznie bardziej obszernego kursu mającego na celu wykształcenie u studentów umiejętności związanych z wyszukiwaniem, selekcją oraz wykorzystywaniem informacji, a w myśl cytowanej wyżej definicji IL przygotowaniem ich do dalszego samokształcenia w tym obszarze wiedzy.

\section{Autorskie badania ankietowe}

Przygotowując projekt implementacji założeń IL na terenie Uniwersytetu Łódzkiego, autorka niniejszego opracowania postanowiła zacząć od ogólnego sprawdzenia stanu wiedzy studentów starszych lat oraz doktorantów na temat elektronicznych narzędzi informacji naukowej dostępnych

${ }^{5}$ S. Bury, dz. cyt., s. 46; H. Julien, K. Williamson, Discourse and practice in information literacy and information seeking: gaps and opportunities, „Information Research” 2010, vol. 15, no. 1, s. [3-4].

${ }^{6}$ Edukacja dorosłych: podręcznik akademicki, red. nauk. M. Knowles, S. Holton, F. III S. Elwood, A. Richard, tłum. M. Habura, R. Ligus, A. Nizińska, Warszawa 2009, s. 237; R. E. Johnson, dz. cyt., s. 36. 
on-line w uczelni oraz tego, co oferują szeroko pojęte zasoby Open Access. Chodziło przede wszystkim o sprawdzenie, na ile studenci interesują się źródłami internetowymi i wychodzą poza informacje dostarczane przez wyszukiwarkę Google. Istotne było także sprawdzenie, czy terminologia związana z wyżej wymienionymi zagadnieniami nie jest im obca oraz czy byliby zainteresowani udziałem w zajęciach praktycznych z tego zakresu.

Przygotowana ankieta była pierwszym z cyklu badań sondażowych, jakie autorka zamierza przeprowadzić $\mathrm{w}$ trakcie wdrażania projektu. W skład tego cyklu będą także wchodzić grupowe badania kwestionariuszowe potrzeb indywidualnych podczas realizacji szkoleń; wywiady z pracownikami naukowymi, których celem będzie określenie obszaru wiedzy potrzebnego studentom i doktorantom do prac badawczych, oraz ankiety sprawdzające poziom satysfakcji po szkoleniu i ocenę własnych kompetencji przez uczestników kursów.

$\mathrm{W}$ omawianym na łamach niniejszego artykułu badaniu ankietowym we wszystkich zagadnieniach problemowych zastosowano pytania półotwarte, wielokrotnego wyboru (dlatego wyniki nie sumują się do 100\%), z możliwością wypowiedzenia swojej opinii przez uczestników. Osoby ankietowane bardzo często korzystały z tej możliwości, co wzbogaciło materiał badawczy, uzupełniając, a niekiedy zmieniając znaczenie wyników pytania głównego.

Badaniem zostali objęci wszyscy studenci (oprócz pierwszorocznych) oraz doktoranci posiadający konto biblioteczne w Bibliotece Uniwersytetu Łódzkiego (dalej: BUŁ), zarówno studiujący na Uniwersytecie Łódzkim, jak i spoza tej uczelni. Korzystając z bazy mailowej, jaka istnieje w elektronicznym systemie wypożyczeń BUŁ, zaproszenie do udziału $\mathrm{w}$ ankiecie, umieszczonej na darmowej stronie $\mathrm{WWW}^{7}, \mathrm{w}$ listopadzie 2011 r. rozesłano do 10500 osób. Odpowiedziało na nią 2569 respondentów (co stanowiło mniej niż 25\% ogółu ankietowanych). Część pytań została sformułowana w taki sposób, aby skłonić badanych do przemyślenia odpowiedzi i zachęcić ich do dodatkowego wypowiedzenia się.

Ogółem w badaniu uczestniczyło 2554 studentów Uniwersytetu Łódzkiego (99,4\%), 7 Politechniki Łódzkiej (0,3\%), 3 Uniwersytetu Medycznego w Łodzi $(0,1 \%)$ i 5 innych $(0,2 \%)$ uczelni państwowych. W grupie tej 48,9\% (1255 studentów) stanowili studenci 1.-3. roku studiów.

${ }^{7}$ Ankieta jest nadal dostępna w Internecie pod adresem http://moje-ankiety.pl/respond-13337.html [dostęp 30 listopada 2012]. 
Nieco mniejszą zbiorowość, bo 42,9\% (tj. 1103 osób), tworzyli studenci 4.-5. roku. Najmniej licznie reprezentowani w badaniu byli doktoranci zaledwie 8,2\% (210 osób).

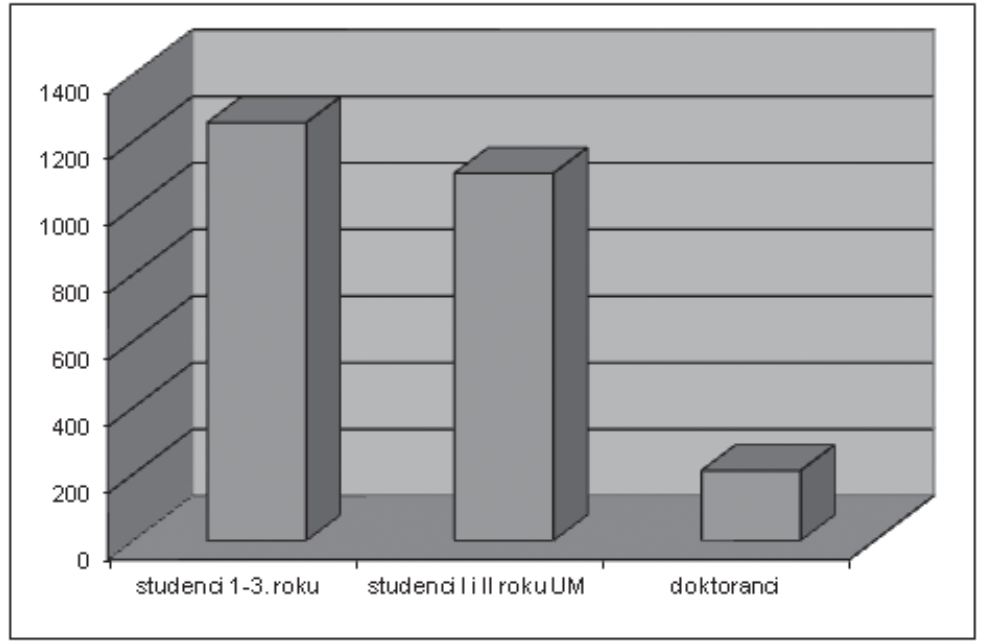

Wykres 1. Studenci biorący udział w badaniu według roczników Źródło: opracowanie własne.

W badaniu wzięli udział studenci studiów licencjackich, magisterskich i doktoranci wszystkich wydziałów Uniwersytetu Łódzkiego oraz nielicznych wydziałów innych uczelni. Tabela 1 ilustruje procentowy udział ankietowanych według wydziałów, które reprezentowali.

Tabela 1. Studenci biorący udział w badaniu według wydziałów Uniwersytetu Łódzkiego

\begin{tabular}{|l|c|c|}
\hline \multicolumn{1}{|c|}{ Wydział } & $\begin{array}{c}\text { Liczba studentów } \\
\text { biorących udział } \\
\text { w badaniu }\end{array}$ & Procentowy udział \\
\hline Wydział Biologii i Ochrony Środowiska & 116 & $4,50 \%$ \\
\hline Wydział Chemii & 36 & $1,40 \%$ \\
\hline Wydział Ekonomiczno-Socjologiczny & 486 & $18,90 \%$ \\
\hline Wydział Filologiczny & 354 & $13,80 \%$ \\
\hline Wydział Filozoficzno-Historyczny & 187 & $7,30 \%$ \\
\hline
\end{tabular}


Ciąg dalszy tabeli 1

\begin{tabular}{|l|c|c|}
\hline \multicolumn{1}{|c|}{ Wydział } & $\begin{array}{c}\text { Liczba studentów } \\
\text { biorących udział } \\
\text { w badaniu }\end{array}$ & Procentowy udział \\
\hline Wydział Fizyki i Informatyki Stosowanej & 13 & $0,50 \%$ \\
\hline Wydział Matematyki i Informatyki & 64 & $2,50 \%$ \\
\hline Wydział Nauk Geograficznych & 182 & $7,10 \%$ \\
\hline Wydział Nauk o Wychowaniu & 287 & $11,20 \%$ \\
\hline Wydział Prawa i Administracji & 334 & $13 \%$ \\
\hline $\begin{array}{l}\text { Wydział Studiów Międzynarodowych } \\
\text { i Politologicznych }\end{array}$ & 116 & $4,50 \%$ \\
\hline Wydział Zarządzania & 320 & $12,50 \%$ \\
\hline Inne / brak informacji & 74 & $2,90 \%$ \\
\hline
\end{tabular}

Źródło: opracowanie własne.

Pytanie czwarte - „Kiedy szukam w Internecie danych naukowych posługuję się:" -poruszało pierwszy problem związany z wyszukiwaniem danych naukowych w zasobach internetowych i miało pokazać, jakie strategie wyszukiwawcze stosują studenci w pracy z wyszukiwarkami. Ze względu na jego treść badani mogli wybrać dowolną liczbę odpowiedzi z czterech podanych oraz dodać własną opinię. Badanie dowiodło, że 97,5\% respondentów prowadzi wyszukiwanie, wpisując do wyszukiwarki słowa bądź frazy. 19,6\% korzysta z linków i połączeń hipertekstowych. 10,6\% posługuje się katalogami zasobów, a 8,4\% stosuje operatory logiczne.

Pytania ankiety, oprócz sprawdzenia konkretnych umiejętności, dzięki zawoalowanej opcji własnej opinii, miały także dostarczyć odpowiedzi na temat wiedzy ankietowanych studentów. W przypadku strategii wyszukiwawczych 30 osób zamieściło swoje opinie, które dowodzą bardzo nierównego poziomu znajomości tych strategii. Podczas gdy niektórzy respondenci podawali nazwy baz, z jakich korzystają, inni wskazywali, że używają opcji wyszukiwania zaawansowanego. 6 osób nie znało wymienionych w pytaniu terminów. Część ankietowanych jako strategię wyszukiwawczą podawała Google (iGoogle Books oraz Scholar) bądź EBSCO, co świadczy o tym, że nie do końca zrozumieli oni, o co chodziło w pytaniu. Jedna osoba jako miejsce pozyskiwania pełnotekstowych informacji wskazała „chomikuj.pl, rapidshare, serwery z nielegalnymi kopiami książek”. 
Pytanie piąte miało na celu sprawdzenie znajomości wybranych terminów z zakresu kompetencji informacyjnych i brzmiało: „Znane mi są następujące terminy". Pod pytaniem została umieszczona lista kilku terminów, z której można było wybrać dowolną ich liczbę. Jak się okazało, największa liczba osób wskazała termin biblioteka cyfrowa $(66,9 \%)$. Na drugim miejscu prawie ex aequo znalazły się książka on-line $(96,5 \%)$ i czasopismo online $(91,2 \%)$. Mniejszą popularnością cieszyły się z kolei: bibliograficzna baza danych $(54,3 \%)$ oraz pełnotekstowa baza danych (23,2\%). Najmniej znanym określeniem okazał się termin repozytorium internetowe $(6,2 \%)$. Ze względu na raczkujące w Polsce akademickie repozytoria internetowe nie dziwi słaba znajomość tej nazwy. Zaskakująca jest natomiast mała liczba wskazań pełnotekstowych baz danych. Jak zauważył jednak jeden z ankietowanych, „desygnaty wielu spośród tych (i innych) terminów są prawdopodobnie dość dobrze znane z praktyki, niekoniecznie zaś z poprawnych nazw". Wyniki badań wyraźnie dowiodły popularności książek i czasopism on-line, a także bibliotek cyfrowych, choć co do poprawnego rozumienia tego terminu przez studentów autorka ma pewne wątpliwości.

Kolejne pytanie dotyczyło właśnie tego typu zasobów. Mimo że biblioteki cyfrowe są narzędziem najbardziej przydatnym historykom, historykom literatury, muzealnikom, biografom, czasem muzykom czy historykom sztuki, pytaniem o korzystanie z nich objęto wszystkich ankietowanych (por. wykres 2).

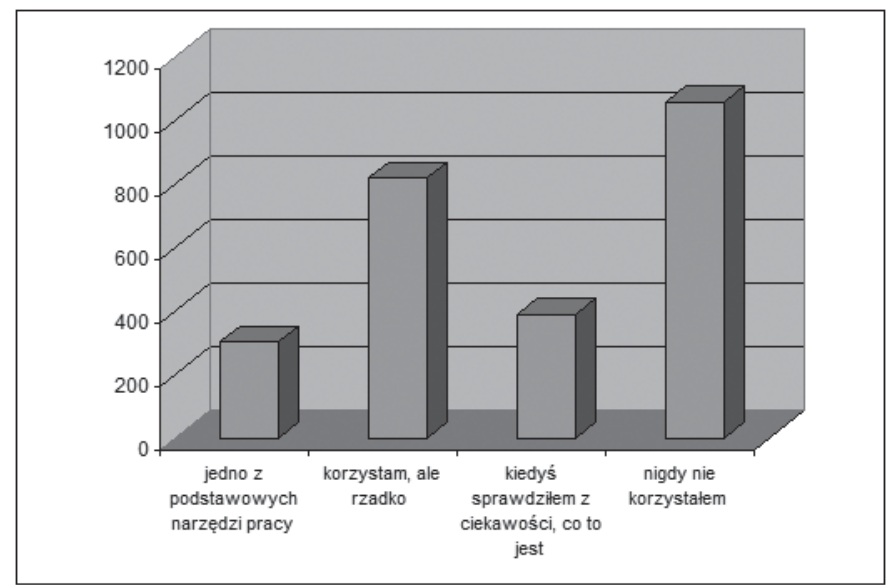

Wykres 2. Odpowiedzi udzielone na pytanie 6: „Biblioteka cyfrowa to dla mnie:” Źródło: opracowanie własne. 
Jak nietrudno zauważyć, ponad $40 \%$ badanych nigdy nie korzystało z biblioteki cyfrowej. Zaledwie dla $12 \%$ ankietowanych stanowi ona podstawowe narzędzie pracy. 30\% korzysta z niego sporadycznie, a 15\% zajrzało do tego typu zasobu przynajmniej raz. 8 osób przyznało nawet, że nie wiedziało o istnieniu takiego źródła. Kilku respondentów pomyliło OPAC z biblioteką cyfrową i nie umiało wskazać centralnych serwisów je udostępniających (np. w Polsce Federacja Bibliotek Cyfrowych). Osoby korzystające regularnie z bibliotek cyfrowych (łącznie ponad 43\%) narzekały na ich zasoby: „Za mało przydatnych materiałów”, „Chciałbym, by było dostępnych więcej pozycji". Tylko jedna osoba sformułowała opinię, że nie korzysta z bibliotek cyfrowych, ponieważ materiałów naukowych z jej dziedziny wiedzy w nich nie ma.

W pytaniu siódmym badani mieli określić, czy korzystają z baz danych. Świadomie nie skonkretyzowano w nim, o jakie bazy chodzi. Wskazano jedynie, że mają to być bazy dostępne on-line ze strony WWW BUŁ. Odpowiedzi udzielone na to pytanie prezentuje wykres 3.

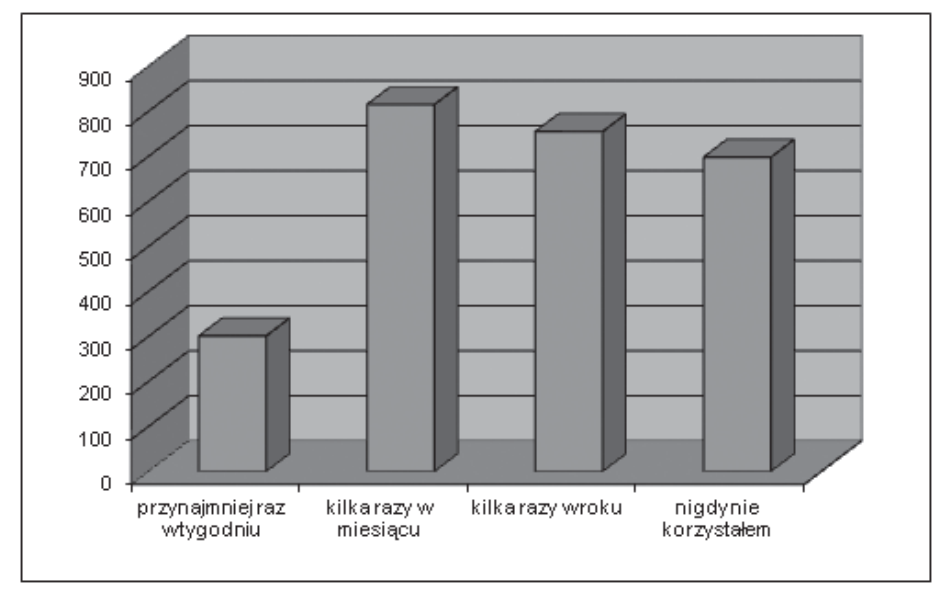

Wykres 3. Odpowiedzi udzielone na pytanie 7: „Z baz danych dostępnych on-line ze strony BU€ korzystam:"

Źródło: opracowanie własne.

Zgromadzone dane dowiodły, że 31,7\% badanych (815 osób) korzysta z baz kilka razy w miesiącu, 29,4\% (755 osób) robi to klika razy w roku. Zaledwie 11,7\% (301 osób) wykorzystuje je przynajmniej raz w tygodniu, natomiast 27,2\% (698 osób) nigdy z nich nie korzystało. 6 re- 
spondentów stwierdziło, że bazą danych jest wyłącznie OPAC. Wielu studentów przyznało się do tego, że nie radzi sobie - nawet ze stosunkowo precyzyjnymi - wyszukiwarkami komercyjnych baz elektronicznych: „Ciężko się w nich poruszać”, „Mam problem z przejrzystym znalezieniem tego, czego szukam, oraz wrażenie chaosu informacyjnego - wyszukiwarki są albo zbyt precyzyjne [sic!], albo zbyt niejasno opisane”, ,Jest straszliwie nieprzystępna dla użytkownika".

Odpowiedzi udzielane na kolejne pytanie: „Informacje wyszukane na stronach internetowych uważam za:" miały wykazać, jak studenci radzą sobie z szumem informacyjnym w Internecie. Okazało się, że $82,1 \%$ badanych potwierdza prawdziwość informacji znalezionych w sieci za pomocą tradycyjnych źródeł informacji, ale aż 15\% uznaje je za w pełni wiarygodne. Dla $2 \%$ nie mają one żadnej wartości, a 0,7\% w ogóle z nich nie korzysta. Pytanie dotyczące Internetu wzbudziło największe zainteresowanie ankietowanych, aż 106 osób opatrzyło bowiem swą odpowiedź dodatkowym komentarzem na ten temat. $W$ opiniach badani zaznaczali, że potwierdzeniem wiarygodności wielu stron WWW jest dla nich nazwa instytucji sprawczej, która odpowiada za witrynę. Część ankietowanych (13 wypowiedzi) sprawdza wiarygodność informacji, porównując ze sobą różne strony internetowe. 3 osoby jako przykłady źródeł informacji niewiarygodnych podają teksty wyszukane w wyszukiwarce Google i Wikipedii. Dwie osoby stwierdziły, że tradycyjne źródła bywają także niewiarygodne i zawierają błędy. Zarówno odpowiedzi udzielone na pytanie zasadnicze, jak i dodatkowe komentarze wykazały dużą świadomość ankietowanych w zakresie przeszukiwania Internetu.

Następne zagadnienie dotyczyło zainteresowania dostępnymi on-line źródłami pełnotekstowymi. Odpowiedzi uzyskane na to pytanie ilustruje wykres 4.

Wyraźnie widać, że największym zainteresowaniem cieszą się elektroniczne edycje książek $(57,4 \%)$ oraz czasopism naukowych $(44,7 \%$ dla czasopism polskich i $29,1 \%$ dla czasopism zagranicznych), a także tekstów literackich (40,7\%). Jednocześnie duża grupa badanych korzysta z dość niszowych, wydawałoby się, dokumentów, jak kopie tekstów źródłowych $(13,9 \%)$, archiwalna prasa $(23,7 \%)$ czy stare druki $(7 \%)$. Należy jednak pamiętać, że dużą grupę ankietowanych (łącznie ponad 20\%, tj. 541 osób) stanowili studenci Wydziałów Filologicznego i Filozoficzno-Historycznego. Ankieta wykazała, że większość z nich korzysta z dostępnych dla tych dziedzin elektronicznych źródeł wiedzy, do których w epo- 
ce „przed Google” ${ }^{8} \mathrm{w}$ ogóle nie miała dostępu. Zaledwie 8 osób, udzielając odpowiedzi na pytanie 9, zaznaczyło, że w ogóle nie korzysta z żadnego z wymienionych źródeł.

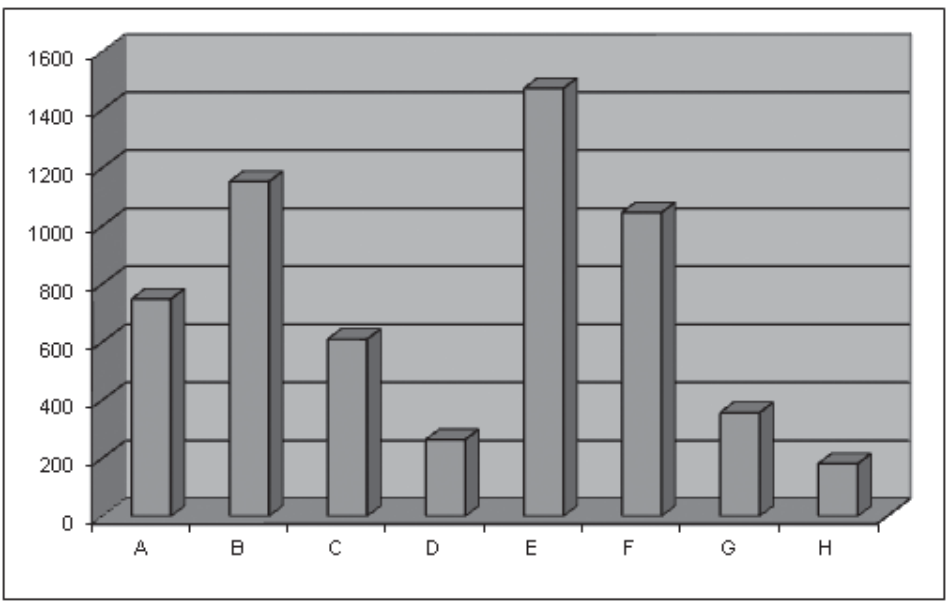

Legenda:

A - artykuły z zagranicznych naukowych czasopism elektronicznych

B - artykuły z polskich naukowych czasopism elektronicznych

C - elektroniczne wersje archiwów współczesnej polskiej prasy codziennej (np. archiwum „Gazety Wyborczej”)

D - polska bądź zagraniczna prasa archiwalna (do początków XX w.)

E - e-książki (Ibuk, Ebrary, biblioteki cyfrowe)

$\mathrm{F}$ - teksty literackie

G - zdigitalizowane kopie historycznych dokumentów i innych tekstów źródłowych

$\mathrm{H}$ - zdigitalizowane stare druki, inkunabuły i rękopisy

Wykres 4. Odpowiedzi udzielone na pytanie 9: „W internetowych źródłach pełnotekstowych (typu Open Access lub bazy danych) najczęściej korzystam z:"

Źródło: opracowanie własne.

Pytanie 10 zawierało nazwy najpopularniejszych i najbardziej znanych wolno dostępnych źródeł pełnotekstowych, istniejących w Internecie, takich jak: Federacja Bibliotek Cyfrowych, Projekt Gutenberg, Europe-

${ }^{8} \mathrm{Z}$ angielskiego terminu $B G$ - before Google, który zaczyna być stosowany powszechnie przy opisywaniu przełomu technologicznego końca XX i początku XXI w., a powstał na wzór $B C$ - before Christ. 
ana, Wolne Lektury, ResearchGATE, Wirtualna Biblioteka Nauki, Directory of Open Access Journals (DOAJ). Najbardziej popularnym zasobem okazał się Projekt Gutenberg. Na jego znajomość wskazało $24,3 \%$ badanych, tj. 623 studentów. Na drugim miejscu znalazła się polska Federacja Bibliotek Cyfrowych (21,8\% - 561 osób). Na podobnym poziomie plasowała się znajomość portalu Wolne Lektury (19\%, 489 osób) oraz zasobów Wirtualnej Biblioteki Nauki (17,6\%, 452 badanych). Kolejne miejsca zajęły: Europeana, na którą wskazało 7,8\% respondentów (201 osób), a następnie Directory of Open Access Journals - 7,6\% (195 badanych). Najmniej znanym zasobem okazał się ResearchGATE, który wybrało 4,1\% ankietowanych (105 osób) (por. wykres 5).

Jak dowodzą wyniki procentowe, nawet najpopularniejszy Projekt Gutenberg jest znany zaledwie niecałej $1 / 4$ respondentów. Ponieważ w tym pytaniu można było zaznaczyć kilka odpowiedzi, rodzi się przypuszczenie, że tylko około $1 / 4$ badanych studentów w ogóle zetknęła się z wyżej wymienionymi nazwami źródeł pełnotekstowych. Niecałe sto osób potwierdziło taką ewentualność w opiniach pod pytaniem, pisząc, że nie zetknęli się z żadną z nazw wyliczonych w pytaniu.

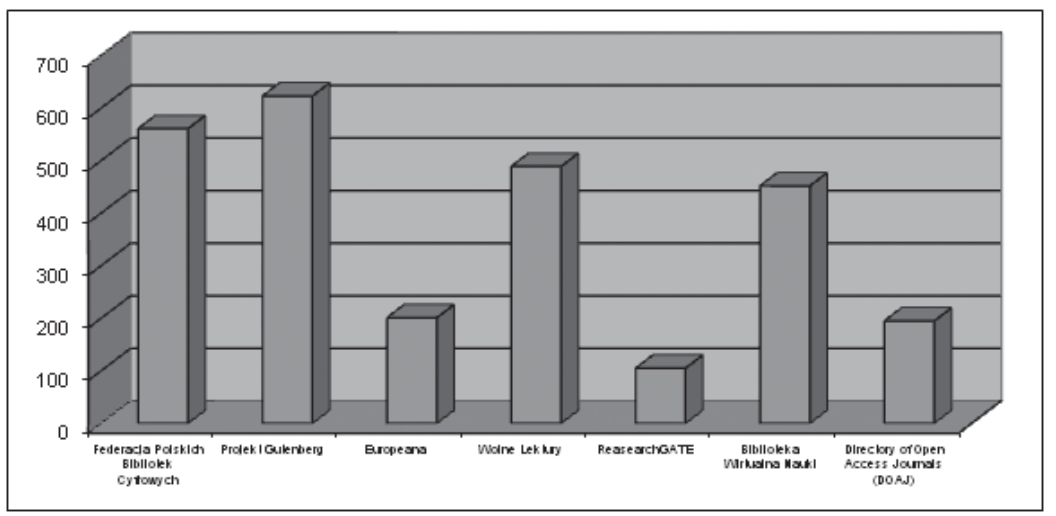

Wykres 5. Odpowiedzi udzielone na pytanie 10: „Podczas poszukiwania potrzebnych mi materiałów naukowych zetknąłem się z nazwami:"

Źródło: opracowanie własne.

W 2008 i 2009 r. autorka przeprowadziła badanie ankietowe wśród czytelników BUŁ ${ }^{9}$, w którym m.in. zapytała o najczęściej wypożyczany

9 J. Jerzyk-Wojtecka, Mechaniczne bariery informacyjne i możliwości ich niwelowania $w$ bibliotece akademickiej na przykładzie Biblioteki Uniwersytetu Łódzkiego - omówienie 
rodzaj publikacji (pytanie 6). Wówczas respondenci wskazali na książki (93\%) i czasopisma (50\%) w formie drukowanej. Z dostępnych on-line czasopism elektronicznych korzystało niespełna 19\% badanych. BUŁ nie posiadała jednak wtedy książek w takiej postaci w swojej kolekcji zasobów elektronicznych. Obecnie przeprowadzona ankieta wyraźnie wskazuje na przemiany technologiczne, a co za tym idzie - także nowe nawyki czytelnicze użytkowników BUŁ.

Ostatnie, merytoryczne pytanie dotyczyło sposobów zbierania materiałów do pracy naukowej (dyplomowej). Uzyskane odpowiedzi dowiodły niezachwianej pozycji dokumentów tradycyjnych (książek - 86,5\% i czasopism - 54,3\%). Niemal połowa respondentów korzysta także z wydawnictw elektronicznych dostępnych on-line (45,4\% dla e-książek i 42,5\% dla e-czasopism). To ponaddwukrotny wzrost w ciągu trzech lat! Truizmem w tej sytuacji jest stwierdzenie, że nabycie odpowiednich kompetencji informacyjnych, ułatwiających korzystanie z tego rodzaju źródeł, w szybkim tempie staje się pierwszorzędną potrzebą użytkowników bibliotek naukowych.

W ostatnim pytaniu studenci mieli wypowiedzieć się, czy byliby zainteresowani udziałem w szkoleniu rozwijającym umiejętności wyszukiwawcze on-line. Połowa badanych opowiedziała się za tego typu kursami, około $15 \%$ nie widziało takiej potrzeby, a nieco ponad $1 / 3$ była niezdecydowana. Podobnie jak w niektórych poprzednich pytaniach, także tutaj wiele do myślenia dają komentarze respondentów zamieszczone pod pytaniem. Studenci postulowali, aby takie szkolenia były ciekawe i dotyczyły bieżących informacji (profesjonalnie przygotowane i przeprowadzone). Część chciałaby w nich uczestniczyć on-line, inni natomiast woleliby przyjść do biblioteki, co wskazuje, jak istotne jest dobre „dopasowanie” zajęć - nie tylko od strony tematycznej i merytorycznej - do szkolonej grupy.

\section{Podsumowanie}

Wyniki ankiety pokazały także, że większość użytkowników przeszukujących Internet w celach naukowych (i pewnie nie tylko) ma świadomość, że znalezione informacje powinny być weryfikowane za pomocą innych źródeł (np. tradycyjnych).

badania czytelniczego, [w:] Jakość usług bibliotecznych $w$ społeczeństwie informacyjnym: praca zbiorowa, pod red. J. Kamińskiej, B. Żołędowskiej-Król, Warszawa 2009, s. 96-104. 
Sama konieczność zorganizowania kursów IL dla studentów starszych lat studiów i doktorantów w świetle przeprowadzonego badania wydaje się oczywista. Istotne jest jednak szczegółowe zaplanowanie programu szkolenia, przystosowanego dla danej grupy uczestników pod względem wymagań nauczycieli akademickich i programu nauczania konkretnego kierunku. Dlatego kolejnymi krokami we wdrażaniu programu IL w BUŁ będą: ankieta uczestnictwa, wywiady i szczegółowe konsultacje dotyczące zakresu szkoleń z pracownikami naukowymi uczelni, zainteresowanymi przeprowadzeniem kursów wśród studentów ich kierunku.

Badanie dowiodło, że większość studentów posiada ogólną wiedzę z zakresu umiejętności wyszukiwawczych, którą należy odpowiednio - w zależności od potrzeb i poziomu danej grupy - pogłębić i rozwinąć w pożądanym kierunku oraz zapoznać studentów z odpowiednią terminologią. Dzięki niemu udało się określić, że najważniejszymi celami edukacyjnymi wdrażanego w BUŁ projektu szkoleń z zakresu information literacy powinny być:

- rozwijanie u szkolonych studentów umiejętności przeszukiwania zasobów sieciowych typu Open Access, znajomości zbiorczych wyszukiwarek, zarówno polskich, jak i zagranicznych, dla takich zasobów;

- wykształcenie umiejętności korzystania z wyszukiwarek różnego typu z wykorzystaniem wszystkich dostępnych strategii wyszukiwawczych (operatory logiczne, znaki umowne - cudzysłów ",, gwiazdka*itp.);

- formułowanie własnych zapytań wyszukiwawczych zaspokajających zarówno potrzeby informacyjne użytkownika, jak i dopasowanych do możliwości danej wyszukiwarki bądź indeksów OPAC.

\section{The program of the implementation information literacy trainings in an academic library on the University Library of tódź example: discussion under the survey pilot study}

ABSTRACT: The introduction of the article shows the basic theoretical issues about implementations of information literacy courses in academic libraries and foreign experience in this matter. Further part of the survey research, in 
which University of Łódź students took part, is considering their knowledge in information literacy and their willingness to participate in information literacy training. In the last part, there are the author's conclusions which make the preliminary directives for the created plan of information literacy courses.

KEYWORDS: information literacy, information literacy courses, information science, information skills, survey research 